\title{
The Mediating Influence of Organizational Culture on Leadership Style and Organizational Commitment
}

\author{
Shih-Nien Lee
}

To Link this Article: http://dx.doi.org/10.6007/IJARBSS/v12-i1/11887

DOI:10.6007/IJARBSS/v12-i1/11887

Received: 09 November 2021, Revised: 12 December 2021, Accepted: 26 December 2021

Published Online: 16 January 2022

In-Text Citation: (Lee, 2022)

To Cite this Article: Lee, S.-N. (2022). The Mediating Influence of Organizational Culture on Leadership Style and Organizational Commitment. International Journal of Academic Research in Business and Social Sciences, 12(1), $730-749$.

\section{Copyright: (c) 2022 The Author(s)}

Published by Human Resource Management Academic Research Society (www.hrmars.com)

This article is published under the Creative Commons Attribution (CC BY 4.0) license. Anyone may reproduce, distribute, translate and create derivative works of this article (for both commercial and non0-commercial purposes), subject to full attribution to the original publication and authors. The full terms of this license may be seen at: http://creativecommons.org/licences/by/4.0/legalcode

\section{Vol. 12, No. 1, 2022, Pg. $730-749$}

Full Terms \& Conditions of access and use can be found at http://hrmars.com/index.php/pages/detail/publication-ethics 


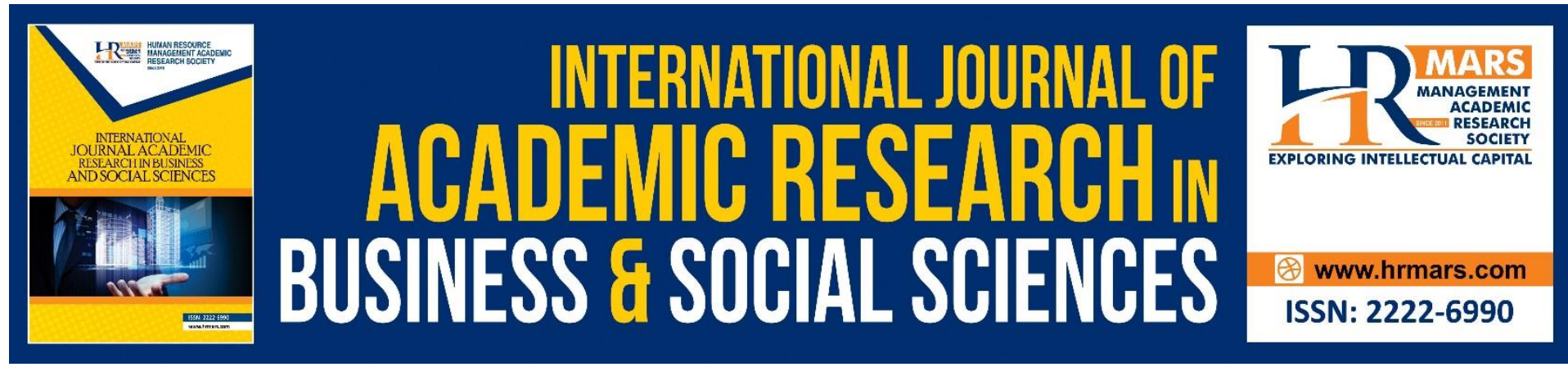

\title{
The Mediating Influence of Organizational Culture on Leadership Style and Organizational Commitment
}

\author{
Shih-Nien Lee \\ Department of PhD Program in Business, School of Business, Feng Chia University, Taiwan
}

\begin{abstract}
This research focuses on the relationship between the leadership style, organizational commitment and organizational culture in primary hospitals. According to previous literature, leadership ability is the ability to influence team vision and mission goals. It is the role of organizational leadership. Due to different types of leaders, As a result, different organizational cultures have been formed. Leaders of the organization and leadership style will result in organizational cultures, and thus to expand its influence on organizational commitment and form affect the validity of the key due to factors. Organizational culture determines the behavior of organizations and individuals, but also affects the organization's strategy, objectives and business operational methods and conduct or leader. Values, behavior and vision can be helpful to the work environment; they are present in every one working environment. The research conducted verification and intermediary verification analysis, and found that it supports the hypothesis of the influence of transformational leadership on organizational emotional commitment; it also presents a positive impact on supportive organizational culture; organizational culture has a partial mediating effect in transformational leadership and organizational commitment.
\end{abstract}

Keywords: Transformational Leadership, Organizational Commitment, Organizational Culture

\section{Introduction}

Economic construction of the achievements of many corporate success, but also has affected the economic cycle fluctuations are eliminated in the enterprise. The same is true for medical institutions. In 2002, there were 610 hospitals in Taiwan, and by 2020, there were only 480 hospitals. The reason is that although a number of factors, but some factors are difficult to measure, such as: knowledge management, organizational culture, leadership style, environment, structure, capital, incentive compensation systems, employee satisfaction, business strategy, as well as technological innovation. From the observation of the company's long-established company's point of view, almost all have the achievements of the company organization has its own unique organizational capital, organizational culture, leadership style, which in turn inspired the organization innovators, such as IBM , Intel, TSMC , Chang Gung Medical, Tzu Chi Medical and so on. Zheng \& McLean (2010) it is noted that most managers believe that a strong organizational culture is very important for the company's 
development, but they also believe that the biggest obstacle the company to adapt to the new environment is the lack of management capacity. Successful companies can make full use of organizational culture and company vision to grow exponentially and become a competitive weapon for the company. Therefore, how organizational culture affects innovation is the motivation of this research.

Leadership can be said that the impact of one kind of another person to change power. Outstanding leaders can gain the trust and respect of group members, and at the same time encourage group members to devote more energy and develop their potential to achieve the goals of the organization. Hult et al (2004) pointed out that if a leader able to adapt to changes in the environment inside and outside the industry, and then create all the staff works to obtain common values and aspirations of new knowledge. Leader owns management mode, as well as management's attitudes and actions, will enhance the organization centripetal force and members gather together the force to become change agents among organizations. The identification with the organization will increase the willingness of employees to share personal knowledge. Therefore, leadership style will be invisible to affect staff work behavior and the company's growth. Each leader also has a different role and growth background, resulting in a variety of leadership styles. The role of a leader in an organization not only affects the performance of the group, but also contributes to the development and innovation of the company. Whether employees can recognize the goals and values of the organization, and then enjoy job satisfaction and dedicate themselves to work. The influence of department heads is very important. From past research literature, it is found that the leadership style of the supervisor affects department satisfaction, productivity and organizational commitment (Wang, 1999; Chen, 2002; McNeese-Smith, 1995). Thus, the second of this study was a motivation to explore the impact of leadership style and organizational innovation.

The main management work is to organize a team that has a high degree of loyalty and performance to the enterprise. To build such an excellent team, the organizational commitment of employees is particularly important. Porter et al (1974) believe that organizational commitment is the willingness to accept organizational goals and values, that is, the degree of recognition and commitment to the organization to which it belongs, the willingness to actively contribute to the organization, and the strong desire to continue pursuing. Organizational commitment has always been the company's management with the leaders of concern. How by strengthening commitment to the organization, Paul left the staff presence and improves their job performance. Therefore, the leadership on organizational commitment, which is the third of this, studies a motive.

This research attempts to explore the relationship between organizational culture, leadership style and organizational commitment, and attempts to find the key to promoting the long-term development of the organization. Based on the above research background and motivation, the purpose of this research is to explore whether organizational culture and leadership style have an impact on organizational commitment.

Specifically, the research goals that this research aims to achieve are:

1. Explore the impact of organizational culture on organizational commitment.

2. Discuss the impact of team leadership style on organizational commitment.

3. Explore whether leadership style and organizational commitment will influence organizational innovation through organizational culture. 


\section{Literature Review \\ Transformational Leadership}

The sociological dictionary explains that "leadership" is a process of interpersonal interaction. It uses influence to guide the behavior of individuals or groups in specific situations, and effectively uses resources to make them tend to achieve specific goals. Katz \& Kahn (1978) believes that leadership comes from other mechanisms outside the organization's conventional norms and is subject to influence outside of them. Leadership is people with the interaction between people in a personal to provide certain information in some way, to make others believe and based on their recommendations or desirable to take action, which can improve the results of behavior. Leadership is the ability to influence employee behavior. Leaders must not only make subordinates conduct routine command of the organization and show compliance in actions, but also strengthen the behavior of subordinates and increase their influence. In 1978, Burns put forward the concept of "leadership" for the first time in his (Leadership) book. According to the behavior characteristics of leaders, he divided the traditional leadership types into two categories: transformational leadership and transactional leadership. For the leadership patterns of this classification has been in use ever since.

Theory, the leadership process assumed the leadership of the transaction under the patterns of behavior, according to the leaders and staff of both the discussions between the work carried out the transaction, that is, employees need to complete the content of the work, employees will get the meet the conditions and award. Under the transformational leadership behavior model, leaders mainly use methods such as disseminating values to stimulate employees' motivation to work and meet their high-level psychological needs; transformational leaders use their own behavior as an example to guide the behavior changes of their subordinates, and at the same time focus on Caring about the individual needs of subordinates, and at the same time strengthen the interaction between members of the organization. On the other hand, by co-creating and propagating the vision of the organization, it creates an atmosphere that is conducive to team change; through subordinates and leaders to promote each other and meet needs, so that employees can devote themselves to work, and ultimately achieve organizational goals. Bass et al., (1985, 1990, 2006) elaborated on the difference between transformational leadership and transactional leadership from the perspective of hierarchy of needs. They believe that the different sources of demand motivation are the main factors that contribute to the two leadership styles. Transactional leadership largely by external demand and expected remuneration rewards unfold, and transformational leadership through motivation of employees to stimulate internal dimension lines (Bass \& Avolio, 1990). Transformational leadership is specifically manifested in the following four behaviors, namely, the personal charm of the leader, the motivation of the vision, the intellectual stimulation, and the personalized care (Bass \& Avolio, 1994). This also constitutes the four dimensions of transformational leadership variables.

In recent few years, changes in the medical environment to hospital managers were extremely severe environmental challenges and tests. Faced with market competition, industrial structure adjustments under the challenge of medical technology, and changes in the market environment, all of these require hospitals to make continuous transformations and changes on the road of operation. These changes may be related to the company's strategy, products, and services, or may be related to the business model and organization. 
Hospitals need to improve their competitiveness, improve efficiency, reduce costs, and improve their technology or service quality through a series of innovative changes and adjustments, so as to promote the transformation and upgrading of hospitals. The key to making these corresponding changes is the hospital's leaders and leadership team. Under the challenge of this kind of change, the leadership ability of the hospital's senior managers and the adaptability of the team can quickly determine whether they can quickly and effectively face the pressure and make adjustments. Therefore, for transformational leaders, how to effectively motivate team members, enable employees to perform tasks better and faster, and have high engagement behaviors, has become a very important research topic in organizational development. We can see from management practice, success of the enterprise, in addition to selecting innovation strategy, organizational strategy of choice, quality and type of organization system of the members of the organization, managers led force has decided the development of enterprises directly affect the nature of (Brown, 1991; Yukl, 1994). Robbins (1996) found that after a comprehensive study of related studies, many scholars advocate that the leadership style of managers has a significant impact on the work effectiveness of their employees. That is, leadership style is an important factor that can affect the overall organizational effectiveness.

Burns (1978); Bass (1985) and others also pointed out that the forward-looking vision and personal charm of transformational leaders can be realized through various motivating leadership behaviors. Through this interactive process, the work motivation and ethics of leaders and subordinates can be improved at the same time, thereby promoting changes in the organization's social system and the entire organization. In At the same time, leaders can motivate employees to increase their level of demand and inspire employees to be aware of their work performance, instead of basing their work performance results on the exchange of rewards and punishments. Leban \& Zulauf (2004) studied 24 project managers from 6 different companies in the United States. The results show that the transformational leadership style of the project manager has a positive impact on actual project performance.

Regional hospital staffs are the main force of primary health care and become the main force of community medical health. The functions and goals of transformational leadership in hospital management include: 1 . Coordination of the hospital environment and organizational functions. 2. Innovative concepts cater to people's needs for healthy development. 3. Hospital managers take the lead in playing an exemplary role. 4 . The learning concept enhances the core competitiveness of the hospital. 5. The concept of human investment guarantees the sustainable development of the medical and nursing professions. 6. Imagine the future development model of the hospital to help define the purpose, goal and vision. 7. Encourage hospital members to move towards the goals and objectives and realize the vision of the organization. 8. Defining the task of the hospital and the work behavior of the staff can be connected to give full play to the work effect. 9. Enhance the core strategy of the hospital and develop the characteristics of the hospital.

\section{Organizational Commitment}

For the study of organizational culture from the 1980's to open start so far by scholar's considerable attention. However, scholars also have many different views on organizational culture. So far, the definition of organizational culture has very diverse interpretations. The earliest overview of the cultural concept from anthropology, think culture is something that human beings need to make a living and created, and people's needs are many. Some are 
necessary for the survival of the body, and some are necessary for the survival of the group. Organizational culture comes from anthropology, and a small part comes from sociology (Smircich, 1983), but the concept and definition of "culture" is different from the literature of anthropology, sociology and management. Schein (1992) pointed out that organizational culture is learning to solve the internal problems of external adaptation and adaptation in response to external (Such as the effects created by strategies, goals, methods, and achievements), discovered or developed the basic assumptions. And internal integration (for example: language, boundaries, power class, rewards and punishments, ideology, etc.). If this hypothesis and effective line of effective, it will be taught to new members, so that they may encounter problems when, in the right way understanding, acceptance, think and feel.

River Wild Fung Hong (1992) pointed out that organizational culture is one kind of values, ideas, opinions, and organizational behavior common to determine one way. Chau-Fu,Lin (2000) studied organizational culture as a combination of values, beliefs, norms, basic assumptions, and behavior patterns shared by members of an organization, which distinguishes organizations from other organizations. Cheng et al (2001) believe that organizational culture is a basic hypothetical model for the organization to deal with external adaptation and internal integration, and it must be used in the way members of the organization recognize, think and perceive. Robbin (2001) also pointed out that organizational culture will be subject to government influence employment policy. Take the process of recruiting and selecting employees as an example. Since the selection decision usually includes whether the candidate is suitable for the company, standards for organizational cultural consistency will be established. In other words, corporate employment policies for the new Jin employees with similar values, and thus accumulate corporate form organizational culture. Hsu (2000) considered as organizational culture is the norm unwritten values and group behavior within the organization. Chang (2003) believe organizational culture of basic assumptions and beliefs a organization faced external competition and internal controls, and realize it's time to develop. It conveys important assumptions and models, governs values and activity goals, and provides the organization with guidelines and norms for members to take action.

Based on the above, the organizational culture is defined as: "In order to respond to changes in the internal and external environments of the organization, maintain the stability and innovation of the organization, share basic assumptions, values, beliefs and norms in order to achieve the highest goals, provide value standards, basic beliefs and members' The code of conduct and the provision of long-term accumulated artifacts are a complex body composed of organizational ideas, materials, and institutional forms. This is a unique phenomenon for organizations."

Wallach (1983) explored the division of organizational culture. 1. Bureaucratic type culture: organizational structure and the division of power and responsibility are very clear; most of the nature of the work is based on standardized or fixed control and power. This type of enterprise is relatively mature and stable, but too cautious. 2. Innovation Type Culture: Organization due to face environmental competition complex, creative work and risk. This is a great importance to staff work challenges and innovation, respect for the individual uniqueness and allow staff working Adventure culture. 3. Support Type Culture: Organization within the work environment presents an open and harmonious, similar to family-like feeling of warmth. In this way the organization has a leader's support and trust, and the importance of participating members, teamwork and interpersonal relationships. Hill \& Jones (2001) 
believes that innovation is the production or manufacturing method of any new products and new products within the company, including the increase of the company's product styles, the development of the production process management system, the development of the organizational structure and the strategy. Robbins (2005) believes that innovation refers to a new idea that can be applied to develop or improve certain new products, processes and services.

Bruce \& Scott (1994) conducted empirical studies, that the leader - member exchange (LMX) for individual innovation behavior of employees has had a significant positive impact. The study of Pillai \& Williams (1998) found that transformational leadership can enhance employee self-efficacy and unity, thereby strengthening organizational commitment among colleagues. Harn-Ru Tsai (2014) research also pointed out that transformational leadership and transactional leadership will have a positive impact on employee job satisfaction and job performance in different situations, creating the best leadership effectiveness for the organization.

The scholar Situ Daxian pointed out: The vitality of an enterprise is maintained by the corporate culture. A strong corporate culture will help the company increase through setbacks and challenges encountered in a long process, and the crisis into a turning point . In a company organization, "people" are users of all resources. Therefore, the corporate culture has increasingly become a concern managers, and company management plays in one kind of role, and even affect the effectiveness of the company (Sheu, 2000). The corporate culture camp formulates organizational vision and consolidates and integrates team consensus and resource functions. By organizational culture driven, it inspired people who value creativity and further development of core competencies of the organization, and ultimately the performance of the company's sustainable competitive advantage (Wen-Kuei, Wong, 2001).

Harvard Business School Professor Frances Frei and Anne Morriss, published in June 2020, "the release of their competencies" (Unleashed) book, they point out: after "director to leave the office, the staff level of commitment to the work, from the company's corporate Culture. Corporate culture illustrates the true style of the company's work." This illustrates the essence of corporate culture: the true style of the company's work. In other words, corporate culture is something that everyone in the company agrees with. The importance of corporate culture is not self-evident, corporate culture guru, MIT Professor Emeritus Sean (Edgar H. Schein) even said: "In what leaders do, the only truly important is, Build and manage the company's corporate culture."

\section{Organizational Culture}

Becker (1960) put forward the concept of organizational commitment and defined that organizational commitment means the power of individual identification and participation in the organization. People determine the angle and degree of contact with the organization, and the main norm is behavior in non-professional roles. The employee's organizational identity and sense of belonging will directly reflect the organization's commitment.

Kant (1968) considered organizational commitment of employees to contribute to the organization and loyalty to the organization of one kind wishes. This continued investment job, eventually because think too much invested in the organization, eventually leading to not want to leave the organization. Porter and other scholars believe that organizational commitment is an important link between employees and the organization, and is the 
internalization of employees' identification with the organization and values. From the attitude level, organizational commitment is defined as the recognition and investment of employees to the organization. Strong desire to become an organization member and willing to make extra efforts to achieve organizational goals (Porter et al., 1974) .

Meyer \& Allen (1991) believes that organizational commitment is an emotional attachment to the organization, which reflects a psychological state of the relationship between employees and the organization, and implies the employee's decision on whether to stay in the organization . Organizational commitment is divided into three main factors: 1 . emotional commitment: individuals in the emotional, psychological to organize one identity and look heavy organizational and personal relationships. Employees are mainly because they have deep feelings for the organization, rather than material benefits, because they organize a kind of emotional dependence, recognition and dedication, as well as loyalty and hard work; 2. Ongoing commitment: based on utilitarian test into account, Unwilling to sacrifice personal abilities for the benefits exchanged for many years of dedication, so I am willing to stay in the organization. This is a commitment to understanding employee must remain in the organization; 3. Regulation Fan commitments: refers to the values due to the loyalty to the organization and must be followed. It reflects the employee to stay stored in the tissues of one kind of obligation liability, which is due to suffer long-term effects of the formation of one kind of social responsibility and commitment of employees to remain in the organization.

Employees and supervisors believe that it is important to maintain an ongoing relationship, and they should try their best to maintain this relationship. In Allen \& Meyer (1990) D Theories organizations of commitment, organizational commitment into San Zhong dimensions: sustained commitment, normative commitment and emotional commitment. Continuous commitment means that employees must continue their relationship with their superiors based on cost considerations; normative commitments mean that employees must continue to keep in touch with their superiors in accordance with their obligations (ShuehChin Ting, 2003 ), and emotional commitments mean that employees must continue based on cost considerations The relationship with the boss. The supervisor is emotionally attached and hopes to continue to build a relationship with the supervisor. Emotional commitment means that members are emotionally attached, identify with and invest in their organization, as well as personal feelings and emotional belonging to the team.

Harris \& Ogbonna (2001) study of leadership styles, organizational culture and organizational performance, the three will each impact. Sarros, Gray \& Densten (2002) believe that there is a positive interaction between leadership style and organizational culture. Wang (2010) found that organizational commitment on turnover intentions, which have a negative impact affective commitment, and normative commitment has a positive significant impact negatively affected. This study explored whether achievement motivation and leadership style affect employees' intention to leave. It turns out that the higher the selfdirected achievement motivation, the lower the turnover tendency. The type of leadership is transactional leadership, the lower the tendency to leave. Transactional leadership and transformational leadership have a significant positive impact on emotional commitment. Yang et al (2014) conducted an empirical study on the correlation between hospital organizational culture and employees' work attitudes, and pointed out that support culture has a positive impact on organizational commitment. If the hospital has a support -type culture, it is full of the work of the staff of the meaning of the work commitment and organizational commitment has a significant impact. 
Based on the above arguments, this research puts forward the following hypotheses:

Hypothesis H1: Transformational leadership has a significant positive impact on supportive organizational culture.

Hypothesis H2: Transformational leadership has a significant positive impact on organizational emotional commitment.

Hypothesis H3: Supportive organizational culture has a significant positive impact on organizational emotional commitment.

Hypothesis H4: Organizational culture plays an intermediary role in the organizational commitment of transformational leadership.

\section{Research Methodology \\ Research Objects and Data Collection}

This study uses convenience sampling questionnaires to collect data. The questionnaires are targeted at grassroots staff from five district hospitals in New Taipei City. In mid-February 2021, the research questionnaire was first randomly assigned to 20 personnel in one of the research hospitals for pre-testing, and the reliability coefficient of the questionnaire was tested through the Cronbach's $\alpha$ value as a comprehensive test. The revised reference materials before the survey and the analysis of the results of the test questionnaire do not require special revision. According to the test results, the Cronbach's $\alpha$ value of the transformational leadership scale is 0.917 , the organizational commitment scale Cronbach's $\alpha$ value is 0.884 , and the organizational culture scale Cronbach's $\alpha$ value is 0.924 . According to the reliability test results of the previous tests above, Cronbach's $\alpha$ value is between 0.88 and 0.93. From late February to mid-March 2021, the official data collection period is 20 days. The method of collecting the questionnaire is to use the nursing chief of the hospital unit to assist his colleagues to fill out the questionnaire and collect the paper questionnaire.

\section{Measurement Tool}

(1) Transformational leadership refers to leaders who will put forward organizational ideas and give their subordinates personalized care and intellectual inspiration. They are also very attractive and can arouse the enthusiasm and dedication of their subordinates in the process of transformation. As far as medical institutions are concerned, it is the best type category for basic-level hospital staff to superior leaders. The research tool refers to the Bass \& Avolio (1995) Leadership Multi-factor Questionnaire (MLQ), which is divided into four dimensions: charm, motivation, intelligent inspiration, and individual care. A total of 12 questions are measured.

(2) Organizational commitment means that employees are willing to contribute labor for the organization and be loyal to the organization, which is a kind of commitment to the organization. In terms of medical institutions, it is the degree to which the emotional commitment of the hospital's grass-roots employees will affect themselves in the hospital's organizational commitment. The research tool refers to the Meyer \& Allen (1991) Organizational Commitment Scale (Original Commitment Scale), with a total of 4 questions for measurement.

(3) In terms of the organizational culture of medical institutions, the working environment of the organization usually has a high spirit of cooperation, which is open and 
harmonious. It has family-like warmth. This type of organization is fair, friendly, supportive, encouraging, and open. And the working environment with a sense of trust, the hospital's grassroots employees agree with the supportive culture in the hospital. The research tool refers to Litwin \& Stringer (1968) \& Wallach (1983) Organizational Culture Index, with a total of 5 questions for measurement.

\section{Data Processing and Analysis}

After returning the questionnaire, the researchers checked the missing or questionable parts of the questionnaire and coded the questionnaire. Use SPSS software for archiving and data analysis, and use Confirmatory Factor Analysis (CFA) to check the reliability and validity of this study. Statistical methods include percentage, mean, standard deviation, Pearson product difference correlation, etc. Descriptive statistical analysis methods are used for the distribution of basic data of research objects, transformational leadership, organizational commitment and organizational culture. In addition, this study uses regression analysis to test the hypothesis verification of this study, explore the relative importance of the personal attributes of the research objects, transformational leadership, organizational commitment, and organizational culture to verify the hypothesis and predict its explanatory power.

\section{Finding and Discussion}

This chapter conducts statistical analysis on the collected questionnaires. This study mainly uses SPSS 20.0 as an analysis tool, and tests and discusses the analysis results based on the above-mentioned purpose and hypothesis.

\section{Sample Recovery and Basic Data Analysis}

1. The situation of sample recovery

In this study, the Department for junior staff five regional hospitals of New Taipei City, a convenience sample survey, random sample questionnaire, and the main purpose is to understand the grass-roots workers in transformational leadership, organizational affective commitment influence, and organizational culture as an agency verification test. Random sampling were issued 160 questionnaires, a total recovery of 154 parts of the questionnaire, after deduction of deletions and incomplete sample, three no effect questionnaire. 151 questionnaires were valid. The total recovery rate was $94.3 \%$. 
2. Analysis of sample basic data

Table 4-1 Basic information of the sample

\begin{tabular}{|c|c|c|c|}
\hline Item & Description & Number of samples & Percentage \\
\hline \multirow{2}{*}{ Gender } & Female & 133 & 88.1 \\
\hline & Male & 18 & 11.9 \\
\hline \multirow{6}{*}{ Age } & Under 25 & 14 & 9.3 \\
\hline & $26-30$ years old & 26 & 17.2 \\
\hline & $31-35$ years old & 38 & 25.2 \\
\hline & $36-40$ years old & 35 & 23.2 \\
\hline & $41-45$ years old & 30 & 19.9 \\
\hline & 46 years and older & 8 & 5.3 \\
\hline \multirow{3}{*}{ Education } & High school & 14 & 9.3 \\
\hline & Specialist & 74 & 49.0 \\
\hline & $\begin{array}{l}\text { University (inclusive) and } \\
\text { above }\end{array}$ & 63 & 41.7 \\
\hline \multirow{3}{*}{ Marriage } & Married & 78 & 51.7 \\
\hline & Unmarried & 68 & 45.0 \\
\hline & Other & 5 & 3.3 \\
\hline \multirow{2}{*}{ Position } & Hired staff & 18 & 11.9 \\
\hline & Official & 133 & 88.1 \\
\hline \multirow{4}{*}{ Seniority } & Less than 1 year & 25 & 16.6 \\
\hline & $2-5$ years & 86 & 57.0 \\
\hline & $6-10$ years & 22 & 14.6 \\
\hline & More than 10 years & 18 & 11.9 \\
\hline \multirow{3}{*}{ Unit } & Outpatient & 46 & 30.5 \\
\hline & Ward & 51 & 33.8 \\
\hline & Other & 54 & 35.8 \\
\hline
\end{tabular}

\section{Reliability and Validity Analysis}

The study used SPSS 20.0 statistical software as a data analysis tool, and confirmed reliability and validity with confirmatory factor analysis (CFA).

1. Reliability analysis

Reliability refers to whether the measurement results of the problem item have the displayed reliability and consistency. Higher reliability represents the balance consistency index higher amount. Table 4-2 organizes comprehensive reliability.

(1) Combination reliability

Combination reliability refers to the consistency or stability of internal variables. The higher the CR value, the higher the consistency of the variables. Table 4-2, the sum of all facets $\mathrm{CR}$ value in all aspects of greater than 0.7 , the reliability of the combination of good (Fornell \& Larcker, 1981). The measurement formula of CR is:

$$
\mathrm{CR}=(\Sigma \text { Loading })^{2} /\left[(\text { LLoading })^{2}+\text { Lerror }\right]
$$


(2) Cronbach's $\alpha$ If the value of $\alpha$ is less than 0.35 , it is a low reliability level, and if the value is greater than 0.7, it is a high reliability level (Ruekert and Churchill, 1984). As shown in Table 4-2, the Cronbach's $\alpha$ value of each facet is close to 0.7 , so it has good reliability.

2. Validity refers to the correctness of interim measurement results, that is, the degree to which each measurement item can correctly measure each research variable. In this study, they are measured by convergence validity.

Convergence validity is measured by the significance level of factor loading and average variance extraction (AVE) (Fornell \& Larcker, 1981). As shown in Table 4-2, the load of the standardization factor of 4-2 in this study is greater than 0.5 and significant $(p<0.01)$, and all AVE values are also close to 0.6 , so it has convergent validity. The formula for measuring the AVE value is:

AVE $=\Sigma$ Loading $^{2} /\left(\Sigma\right.$ Loading $^{2}+$ Lerror $)$

Table 4-2 Confirmation Analysis and Reliability and Validity Analysis of Aspects

\begin{tabular}{|c|c|}
\hline Variables and measurement items & $\begin{array}{l}\text { Standardized } \\
\text { factor } \\
\text { loading }\end{array}$ \\
\hline \multicolumn{2}{|l|}{ Charm (Cronbach's $\alpha=0.656, \mathrm{CR}=0.820, \mathrm{AVE}=0.604$ ) } \\
\hline $\begin{array}{l}\text { The supervisor is serious about his work and devoted himself to } \\
\text { making others feel happy to be with him. }\end{array}$ & 0.779 \\
\hline $\begin{array}{l}\text { The supervisor trusts the members, which is an attitude of showing } \\
\text { that they are not suspicious of employing people and that they are } \\
\text { not used by others. }\end{array}$ & 0.842 \\
\hline $\begin{array}{l}\text { The supervisor is magnanimous, has a democratic and tolerant } \\
\text { demeanor, and makes people proud to work with him. }\end{array}$ & 0.704 \\
\hline \multicolumn{2}{|l|}{ Stimulating engine (Cronbach's $\alpha=0.590, C R=0.797, A V E=0.571$ ) } \\
\hline $\begin{array}{l}\text { The supervisor will stimulate team consciousness in speech and } \\
\text { behavior, express our common goals, and let us know what we } \\
\text { should do. }\end{array}$ & 0.797 \\
\hline $\begin{array}{l}\text { The supervisor will put forward ideas that are in line with attracting } \\
\text { us, so that everyone can work hard to achieve their ideals. }\end{array}$ & 0.833 \\
\hline $\begin{array}{l}\text { The supervisor's ideas and views on the matter, to help everyone } \\
\text { share the meaning in the work. }\end{array}$ & 0.619 \\
\hline \multicolumn{2}{|l|}{ Intelligent inspiration (Cronbach's $\alpha=0.591, \mathrm{CR}=0.786, \mathrm{AVE}=0.556$ ) } \\
\hline $\begin{array}{l}\text { The supervisor can think deeply about the problem and overcome } \\
\text { the problem to solve it. I learned a new way from him (her). }\end{array}$ & 0.828 \\
\hline $\begin{array}{l}\text { The supervisor himself is self-motivated and constantly learns new } \\
\text { knowledge, which influences the members and provides me with } \\
\text { new ways to solve the confusion. }\end{array}$ & 0.811 \\
\hline $\begin{array}{l}\text { The supervisor can create a creative environment that allows us to } \\
\text { use our imagination. Allows me to rethink ideas that have been } \\
\text { questioned before. }\end{array}$ & 0.570 \\
\hline
\end{tabular}


Table 4-2 Confirmation Analysis and Reliability and Validity Analysis of Aspects

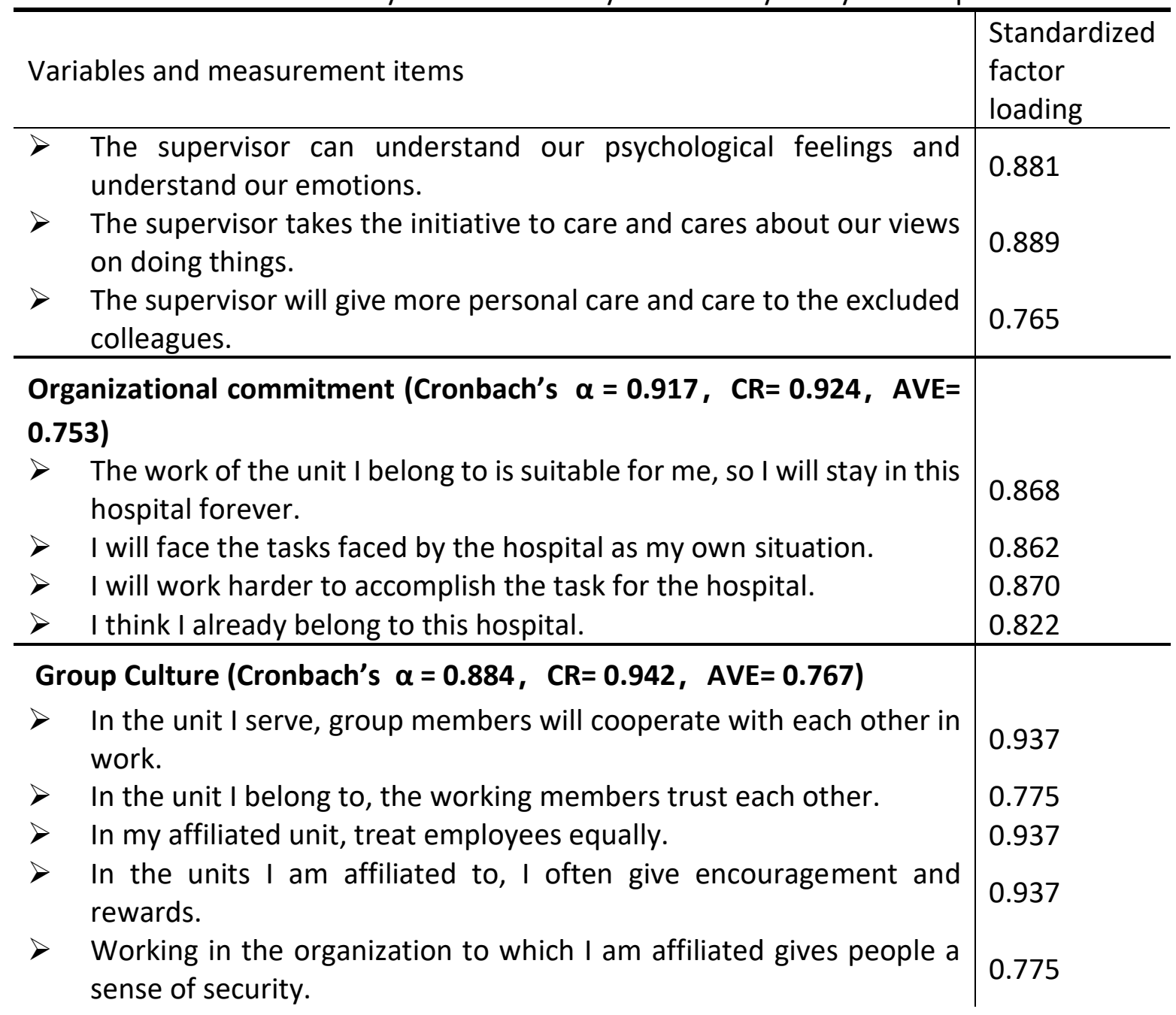

3. Descriptive statistics and related analysis of the dimensions.

The research on several issues of transformational leadership, organizational commitment and organizational culture is measured using a Likert five-point scale. Table 4-3 shows the average and standard deviation of each measurement item.

Table 4-3 Descriptive statistical analysis of dimensions

\begin{tabular}{|c|c|c|c|}
\hline Variables and measurement items & $\begin{array}{l}\text { Average } \\
\text { value }\end{array}$ & $\begin{array}{l}\text { Standard } \\
\text { deviation }\end{array}$ & $\begin{array}{l}\text { Average } \\
\text { ranking }\end{array}$ \\
\hline $\begin{array}{l}\text { Charm (Cronbach's } \alpha=0.656, \mathrm{CR}=0.820, \mathrm{AVE}= \\
0.604 \text { ) }\end{array}$ & & & \\
\hline $\begin{array}{l}\text { The supervisor is serious about his work and } \\
\text { devoted himself to making others feel happy to be } \\
\text { with him. }\end{array}$ & 3.37 & 1.056 & 2 \\
\hline $\begin{array}{l}\text { The supervisor trusts the members, which is an } \\
\text { attitude of showing that they are not suspicious of } \\
\text { employing people and that they are not used by } \\
\text { others. }\end{array}$ & 3.61 & 0.783 & 1 \\
\hline$>$ The supervisor is magnanimous, has a democratic & 3.12 & 0.832 & 3 \\
\hline
\end{tabular}


Table 4-3 Descriptive statistical analysis of dimensions

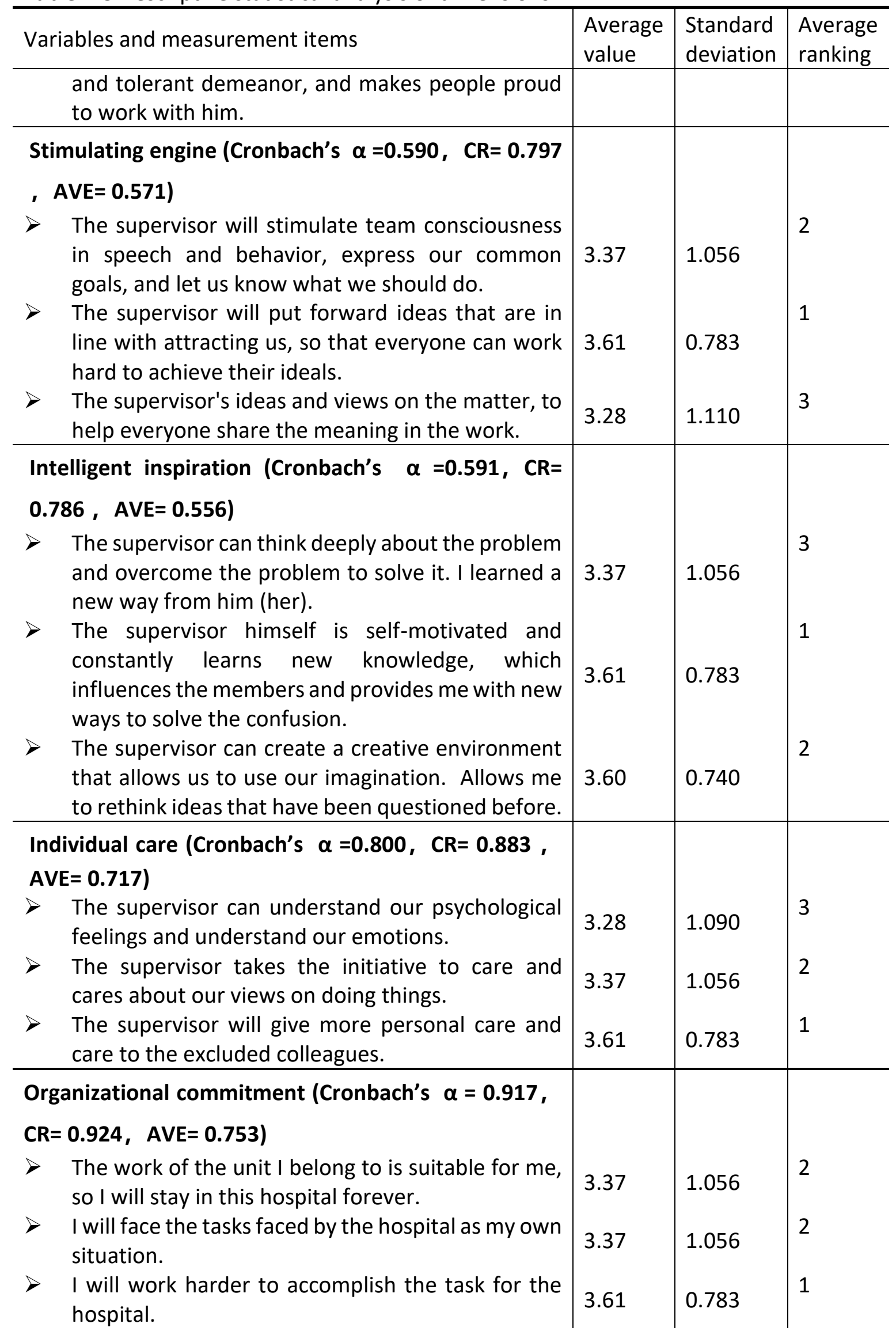


Table 4-3 Descriptive statistical analysis of dimensions

\begin{tabular}{l|l|l|l}
\hline Variables and measurement items & $\begin{array}{l}\text { Average } \\
\text { value }\end{array}$ & $\begin{array}{l}\text { Standard } \\
\text { deviation }\end{array}$ & $\begin{array}{l}\text { Average } \\
\text { ranking }\end{array}$ \\
\hline$>\quad$ I think I already belong to this hospital. & 3.61 & 0.783 & 1 \\
\hline $\begin{array}{l}\text { Group Culture (Cronbach's } \boldsymbol{\alpha}=\mathbf{0 . 8 8 4}, \mathbf{C R}=\mathbf{0 . 9 4 2}, \\
\text { AVE= 0.767) }\end{array}$ & & & \\
$\begin{array}{l}\text { In the unit I serve, group members will cooperate } \\
\text { with each other in work. }\end{array}$ & 3.37 & 1.056 & 2 \\
$\quad \begin{array}{l}\text { In the unit I belong to, the working members trust } \\
\text { each other. }\end{array}$ & 3.61 & 0.783 & 1 \\
$>\quad$ In my affiliated unit, treat employees equally. \\
$\quad \begin{array}{l}\text { In the units I am affiliated to, I often give } \\
\text { encouragement and rewards. }\end{array}$ & 3.37 & 1.056 & 2 \\
$\begin{array}{l}\text { Working in the organization to which I am affiliated } \\
\text { gives people a sense of security. }\end{array}$ & 3.61 & 0.783 & 1
\end{tabular}

\section{Hypothesis Verification}

This study uses the SPSS 20.0 statistical suite as a data analysis tool, and uses regression analysis to verify the hypothesis of this study.

This study uses linear regression as a hypothesis verification tool. Linear regression is a tool to analyze the relationship between variables and variables, mainly to explore the linear relationship between the independent variable $(x)$ and the dependent variable $(y)$.

Linear regression: $y=60+61 x$

In the regression model, R-squared will be used to explain the explanatory power of the entire model, but due to the influence of sample size, $R 2$ will be overestimated. The smaller the sample, the greater the possibility of problems. Therefore, most scholars use the adjusted $\mathrm{R} 2$, which is the total change of the error change and the dependent variable ( $\mathrm{Y}$ ) divided by the degrees of freedom. The closer the value is to 1 , the better the fit of the regression model. Regarding the verification part of the mediation effect, this study uses the SPSS regression model verification method to verify the mediation effect according to the mediation model verification method proposed by Baron \& Kenny (1986). The intermediate variable is the third variable that shows how the independent variable affects the outcome of the variable. In other words, the indirect influence we are discussing is that the independent variable affects the dependent variable through the intermediate variable. Intermediaries are added to the analysis. After the variable can only explain part of the effect (for example, the direct effect is obviously weakened), it is called partial mediation; if the influence of the independent variable and the outcome variable is reduced to an insignificant degree due to the addition of the intermediate variable, it is called Fully intermediary. Organize the hypothesis verification results from Table 4-4.

\section{Hypothesis verification}

Through empirical analysis, this part verifies the hypothesis of this research, and summarizes the standardization coefficients and hypothesis results of the detection model in Table 4-4 and explains them. 
Table 4-4 Hypothesis results

\begin{tabular}{|c|c|c|c|c|}
\hline Hypothesis & $\begin{array}{l}\text { Standardizat } \\
\text { ion factor }\end{array}$ & $\mathrm{t}$ value & $\begin{array}{l}\text { Adjust } \\
\text { ed } R \\
\text { square }\end{array}$ & $\begin{array}{l}\text { Outcome } \\
\text { of } \\
\text { Practice }\end{array}$ \\
\hline $\begin{array}{l}\text { H1: Transformational leadership has a } \\
\text { significant positive impact on organizational } \\
\text { culture. }\end{array}$ & $0.969 * *$ & 47.612 & 0.938 & $\begin{array}{l}\text { Establish } \\
\text { ed }\end{array}$ \\
\hline $\begin{array}{l}\text { H2: Transformational leadership has a } \\
\text { significant positive impact on organizational } \\
\text { commitment. }\end{array}$ & $0.976 * *$ & 54.817 & 0.952 & $\begin{array}{l}\text { Establish } \\
\text { ed }\end{array}$ \\
\hline $\begin{array}{l}\text { H3: Organizational culture has a significant } \\
\text { positive impact on organizational commitment. }\end{array}$ & $0.994 * *$ & 114.212 & 0.989 & $\begin{array}{l}\text { Establish } \\
\text { ed }\end{array}$ \\
\hline \multicolumn{5}{|c|}{$\begin{array}{l}\text { H4: Organizational culture has an intermediary effect in the } \\
\text { transformational leadership's commitment to the organization. }\end{array}$} \\
\hline $\begin{array}{l}\text { 4.1 The effect of transformational leadership on } \\
\text { organizational commitment }\end{array}$ & $0.974 * *$ & 52.929 & 0.949 & \multirow[t]{2}{*}{$\begin{array}{l}\text { Establish } \\
\text { ed }\end{array}$} \\
\hline $\begin{array}{l}\text { 4.2 The effect of transformational leadership } \\
\text { and organizational culture on organizational } \\
\text { commitment }\end{array}$ & $0.179 * *$ & 5.551 & 0.991 & \\
\hline
\end{tabular}

Note: ${ }^{*} \mathrm{P}<0.05 ; * * \mathrm{P}<0.01$ 。

Table 4-4 shown, transformational leadership on organizational culture was positive and significant influence $(\beta=0.969, t=47.612, P<0.01)$, represents a change leadership will be positive affect tissue culture, so the hypothesis $\mathrm{H} 1$ established .

(2) The impact of transformational leadership on organizational commitment

H2: Transformational leadership has a significant positive impact on organizational commitment.

Table 4-4, the change leadership commitment tissue was positive and significant influence $(\beta=0.976, t=54.817, P<0.01)$, represents a change leadership will positively affect organizational commitment, so hypothesis $\mathrm{H} 2$ Established.

(3) The impact of organizational culture on organizational commitments

H3: Organizational culture has a significant positive impact on organizational commitment.

Table 4-4 shown, tissue culture organizational commitment has significant and positive impact $(\beta=0.994, t=114.212, P<0.01)$, indicates tissue culture would positive influence organizational commitment, so hypothesis $\mathrm{H} 3$ was established.

(4) Intermediary effect of organizational culture

H4: Organizational culture has an intermediary effect in the transformational leadership's commitment to the organization.

Table 4-5 is shown, the tissue change leadership commitments $\beta=0.974, t=52.929$, $P<0.01$, change leadership and tissue culture tissue commitments $\beta=0.179, t=5.551, P<0.01$, the standardization coefficient has dropped significantly and is still significant, indicating that organizational culture has a partial mediating effect in transformational leadership and organizational commitment, so Hypothesis $\mathrm{H} 4$ is established. 


\section{Analysis Conclusion}

Table 4- 4 shows that transformational leadership on organizational culture and organizational commitment influence are established, organizational commitment is greater than the impact of organizational culture; transformational leadership and organizational culture are set up for the impact of organizational commitment, organizational culture is greater than the impact of change Type-oriented leadership means that transformational leadership has an influential effect on organizational commitment through organizational culture. All assumptions are the same as the results confirmed by previous scholars.

\section{Conclusion and Discussion Conclusion}

In the process of research, it was discovered that medical institutions are also facing industrial globalization, which has a huge impact on hospital management. If the organization cannot timely revise environmental changes or change its leadership style, it will be marginalized due to multiple errors in policies or management styles that do not conform to the trend of the times. In the face of such a shock, how to enhance competitiveness is closely related to the future development of the hospital. The most important core competitiveness of a hospital comes from the employees of the organization. If the successful operation of the hospital is inseparable from the work of excellent grassroots employees, then the service competitiveness will be difficult to maintain. Therefore, the hospital's high centripetal force and low employee turnover rate will become the basis for stable development. Note hospitals should be more Italian leadership style organization supervisor. The leadership ability of the supervisor affects the first impression of the company's grassroots employees; and the hospital's organizational culture must be emphasized, and the organizational chart must be appropriately modified when necessary to make the employees abide by the organization charter. Pierce \& Nwerstrom (2006) believe that leadership is a dynamic relationship that is established over time, and involve communication between leaders and followers. Its mission is to guide members in the direction of achieving organizational goals; therefore, leaders must continue to communicate with followers. By understanding what employees think, they will spend half of their energy on making policies or executing orders to get more results. What employees want are not only material returns, but also psychological maintenance. Therefore, employees can only feel valued. Only with organizational identity, the organization can continue to flourish; the staff was able to produce emotional commitment to the organization.

Because the nature of the organizational culture of medical institutions is often conservative and obedient. Therefore, the mentality of employees is more or less influenced by the hospital and tends to be conservative. Therefore, when the hospital is faced with risks and changes, it can be seen that only the unit responsible for the business is performing tasks while other units do not actively express support, or even in a passive behavior mode. If we can cultivate a proactive organizational culture, "wholeheartedly, overcome difficulties together", then it can be used in time when faced with the test of epidemics (Qiu Wenda, 2003). In general, all members should be aware of the "community of life", not only to help themselves, but also to help others, in order to give full play to the strength of the team. 


\section{Discussion}

This study aims to study and verify the grassroots employees of five regional hospitals. Due to time and manpower constraints, it is impossible to expand the grassroots staff of other hospitals in other types and throughout the region. In addition, the scope of the study was hospital-level employees, not including the high -order leader. Therefore, the research conclusions cannot represent the actual thinking of the leaders of the entire region and the hospital. However, if the research object can be expanded in the future, for example, the entire medical institution in the region can be used as the research object, then the application of the core structure of the research can be verified. Here, it is suggested that follow-up research can use other types of organizational culture to influence organizational emotional commitment, and then add various variables to study whether the hypothetical model has changed due to the addition of other variables, and it can also be used to confirm the higher the organizational effectiveness. The higher the expectations of the organizational culture.

\section{References}

Allen, N. J., \& Meyer, J. P. (1990). The measurement and antecedents of affective, ontinuance, and normative commitment to the organization. Journal of Occupational Psychology. 63, 1-18.

Baron, R. M., \& Kenny, D. A. (1986). The moderator-mediator variable distinction in social psychological research: Conceptual, strategic and statistical considerations. Journal of Personality and Social Psychology, 51, 1173-1182.

Bass, B. M. \& Avolio, B. J. (1990). Developing transformational leadership: 1992 and beyond. Journal of European Industrial Training, 14, 21-27.

Bass, B. M. (1985). Leadership and performance beyond expectations. New York:Free Press.

Bass, B. M., \& Avolio, B. J. (1994). Improving organizational effectiveness through transformational leadership. Sage, Thousand Oaks, CA.

Bass, B. M., \& Avolio, B. J. (1995) . Multifactor leadership questionnaire: form 5x-short. Menlo Park, CA: Mind Garden.

Bass, B. M., \& Avolio, B. J. (2000). MLQ: Multifactor questionnaire: Third edition manual and sampler set. Redwood City, CA: Mind Garden.

Bass, B. M. (1990). Bass \& Stogdill's Handbook of leadership: Theory, research, and managerial applications. New York: The Free Press.

Becker, H. S. (1960). Notes on the concept of commitment, American Journal of Sociology,66, 32-40.

Brown, R. L. (1991). Critical attributes of instructional leadership in nationally recognized secondary-level blue ribbon schools. Unpublished Doctoral Dissertation, East Texas State University, Texas. 1991

Burns, J. M. (1978). Leadership. New York: Harper \& Row.

Charles W. L. Hill, \& Gareth, R. J. (2001). Strategic management theory:an integrated approach, (5thed), Boston: Houghton Mifflin Co.

Chau-Fu,L. (2000). The Relationship between Organizational Culture and Organizational Effectiveness in the County/City Education Bureaus, an unpublished doctoral dissertation by the Institute of Education, National Taiwan Normal University.

Fornell, C., Larcker, D. F. (1983) Evaluating structural equation models with unobservable variables and measurement error. J Mark Res 1981;18(1):39-50. 
Tsai, H-R. (2014). A Study of the Middle Managers' Leadership Behaviors on Leadership effectiveness. Institute of International Business Management, National Sun Yat-sen University, Kaohsiung City.

Hsin-Chi, C. (2003). The study of the relationship between the management mode of the principals of the national elementary schools and the school organization culture. Master's thesis of National Education Institute of National Pingtung Normal University.

Hult, G. T. M., Hurley, R. F., and Knight, G. A. (2004) Innovativeness: Its Antecedents and Impact on Business Performance. Industrial Marketing Management, 33, 429438.http://dx.doi.org/10.1016/j.indmarman.2003.08.015

Wang, J-M. (2010). A Study on the Relationships among the Need for Achievement, Organizational Commitment and Turnover Intention of Life Insurance Agents and the Supervisors Leadership Styles, Master's thesis from the Institute of Business Administration, Tamkang University.

Kanter, R. M. (1968). Commitment and social organization: A study of commitment mechanisms in utopian communities. American Sociological Review, 33(4), 499-517. https://doi.org/10.2307/2092438

Wang, L. (1999). Leadership style, Job satisfaction, Organizational commitment, and Turnover tendency among hospital organization. Master's Thesis of the Institute of Public Health, University of Kaohsiung Medical College.

Leban, W., \& Zulauf, C. (2004).Linking Emotional Intelligence Abilities and Transformational Leadership Styles, Leadership \& Organization Development Journal, Bradford, 25, 7/8 , pp.554.

Litwin, G. L., \& Stringer, R. A. Jr. (1968). Motivation and Organizational Climate. Boston: Dovision of Research. Granduate School of Business Administration, Harvard University, 1968.

McNeese-Smith, D. (1995) Job Satisfaction, Productivity, and Organizational Commitment. Journal of Nurse Association, 25, 17-26. http://dx.doi.org/10.1097/00005110199509000-00006

Meyer, J. P., \& Allen, N. J. (1991) , A three-component conceptualization of organizational commitment, Human Resource Management Review, 1, 61-98.

Hsu, P. (2000). Organizational Performance Evaluation in the Age of Innovation-Performance Evaluation. World Culture: Taipei.

Pierce, J. L., \& Newstrom, J. W. (2006). Leaders \& the leadership process: Readings, selfassessments \& applications (4th ed.). Boston: McGraw-Hill.

Pillai, R., \& Williams, E. A. (1998). Does leadership matter in the political arena? Voter perceptions of candidates' transformational and charismatic leadership and the 1996 US president. The Leadership Quarterly, 9(3), 397-416.

Porter, L. W., Steers, R. M., Mowday, R. T., \& Boulian, P. V. (1974). Organizational Commitment, Job Satisfaction, and Turnover among Psychiatric Technicians. Journal of Applied Psychology, 59, 603-609.http://dx.doi.org/10.1037/h0037335

Robbins, S. P. (2001). Organizational Behavior,9th ed.Prentice Hall, N. J.

Robbins, S. P. (2005). Essentials of Organizational Behavior. 8th Edition, Pearson Education Inc., Prentice Hall, Upper Saddle River.

Robbins, S. P.(1996). Organizational Behavior: Cooncepts, controversies, and applications. 7th ed., Englewood Cliffs, N.J.: Prentice Hall. 
Ruekert, R. W., \& Churchill Jr., G. A. (1984). Reliability and Validity of Alternative Measures of Channel Member Satisfaction. Journal of Marketing Research, 21, 226233.http://dx.doi.org/10.2307/3151706

Sarros, J. C., Gray, J., \& Densten, I. L. (2002). Leadership and Its Impact on Organizational Culture, International Journal of Business Studies. 102 , pp. 125.

Schein, E. H. (1985, 1992). Organizational Culture and Leadership: A Dynamic View. San Francisco: Jossey-Bass.

Scott, S. G., \& Bruce, R. A. (1994). Determinants of innovative behavior: A path model of individual innovation in the workplace. Academy of Management Journal, 37(3): 580607.

Smircich, L. (1983). Concepts of Culture and Organizational Analysis. Administrative Science Quarterly, 28, 339-358.

Kono, T. (1992). Transforming Corporate Culture, Taipei: Yuanliu Publishing House.

Wallach, E. J. (1983). Individuals and organizations: The cultural match. Training \& Development Journal, 37(2), 28-36.

Wen-Kuei, W. (2001). Research on Corporate Culture Transference- A Case Study of President Enterprise Conglomerate. National Kaohsiung First Division. Master's Thesis of Marketing and Circulation Management Department of University of Technology, unpublished, Kaohsiung City.

Chen, Wu-C. (2002), Research on the Relationship between Organizational Culture, Leadership Behavior, Work Satisfaction, and Organizational Commitment-Taking the Jianan District Bank as an Example. Master's Thesis of the Institute of Business Management, National Cheng Kung University.

Sheu, Y-H. (2002). Gender、Dependence、Employability: Women's Economic Vulnerability and Security in Taiwan. National Taiwan University Social Work Journal, 6, 123-173.

Yukl, G. (1994). Leadership in Organizations. 3rd Edition, Prentice Hall. Upper Saddle River.

Zheng, W., Yang, B., \& McLean, G. N. (2010). Linking organizational culture, structure, strategy, and organizational effectiveness: Mediating role of knowledge management. Journal of Business Research, 63(7), 763-771. https://doi.org/10.1016/j.jbusres.2009.06.005 